\title{
Effect of Different Carbon Sources on Electrochemical Performance of $\mathrm{LiFePO}_{4} / \mathrm{C}$
}

\author{
Cunsi Sun, Zheng Zhang, Mingming Wang, Hongzhou Yang, Yanmin Gao*
}

School of Materials Science and Engineering, Jiangsu University of Science and Technology, Jiangsu, Zhenjiang 212003, China

*E-mail: JUSTGaoYanmin@163.com

doi: $10.20964 / 2020.11 .57$

Received: 18 July 2020 / Accepted: 16 September 2020 / Published: 30 September 2020

In this paper, $\mathrm{LiFePO}_{4} / \mathrm{C}$ material was prepared by hydrothermal method. The effects of organic carbon source ascorbic acid, glucose and inorganic carbon source acetylene black on the properties of materials were studied. The specific capacity of the first discharge at $0.2 \mathrm{C}$ of the three kinds of carbon coated lithium iron phosphate reached $132.5 \mathrm{mAh} / \mathrm{g}, 128.1 \mathrm{mAh} / \mathrm{g}$ and $126.2 \mathrm{mAh} / \mathrm{g}$, respectively. Experiments show that the electrochemical performance of the $\mathrm{LiFePO}_{4}$ coated with ascorbic acid is best. With ascorbic acid as the carbon source, when the addition amount of ascorbic acid was 5\%,7\% and 10\%, the first discharge specific capacity reached $132.5 \mathrm{~m} \mathrm{Ah} / \mathrm{g}, 156.9 \mathrm{~m} \mathrm{Ah} / \mathrm{g}$ and $130.8 \mathrm{~m} \mathrm{Ah} / \mathrm{g}$, respectively. The results show that when the addition amount of ascorbic acid is $7 \%$, the electrochemical performance is the best, reaching more than $90 \%$ of the theoretical capacity of $\mathrm{LiFePO}_{4}$. After 100 charge and discharge cycles at $0.2 \mathrm{C}$, the capacity retention rate is still $97.1 \%$.

Keyword: Lithium-ion batteries; hydrothermal method; Carbon coating; $\mathrm{FePO}_{4}$ precursor; $\mathrm{LiFePO}_{4}$ positive electrode material

\section{FULL TEXT}

(C) 2020 The Authors. Published by ESG (www.electrochemsci.org). This article is an open access article distributed under the terms and conditions of the Creative Commons Attribution license (http://creativecommons.org/licenses/by/4.0/). 